\title{
Hydroxyproline determination in serum and gingival crevicular fluid
}

\section{G. K. Svanberg}

University of Michigan School of Dentistry, Ann Arbor, MI, U.S.A.

\section{Svanberg GK. Hydroxyproline determination in serum and gingival crevicular fluid. Journal of Periodontal Research 1987; 22: 133-138.}

\begin{abstract}
A high-performance liquid chromatographic assay for total hydroxyproline in serum and gingival crevicular fluid has been developed. The Clq component of the first complement factor was precipitated out of the samples with a $0.02 \mathrm{M}$ sodium acetate solution. Aliquots of the supernatants were dried, vapor hydrolyzed with $6 \mathrm{M}$ hydrochloric acid at $105^{\circ} \mathrm{C}$ for 24 hours and derivatized with phenylisothiocyanate. The derivatives were chromatographed using a multilinear solvent gradient with detection at $254 \mathrm{~nm}$. The regression of peak areas on the concentrations of hydroxyproline was linear with a correlation coefficient of 0.99 within the range of assayed quantities ( 2.5 to $25 \mathrm{ng}$ ). Analytical recovery was $90.5 \pm 2.54 \%(\overline{\mathrm{X}} \pm \mathrm{SD})$ and the determination level was $2.5 \mathrm{ng}(19.1 \mathrm{pmol})$. The precision of the assay as determined by the coefficient of variation for five consecutive runs of six concentrations of hydroxyproline in serum hydrolysate ("within-run" precision) and five series run on different days ("between-run" precision) was $1.8 \pm 1.28 \%$ and $4.2 \pm 2.59 \%(\overline{\mathrm{X}} \pm \mathrm{SD})$, respectively. Hydroxyproline concentrations in GCF from single sites during developing experimental gingivitis in the beagle dog showed an irregular pattern of low and high concentrations ranging from 5.2 to $17.4 \mathrm{ng} / \mu 1$.
\end{abstract}

\section{Introduction}

Inflammation and destruction of gingival connective tissue are early and continuing events in the periodontal disease process. Gingival crevicular fluid (GCF) is an inflammatory exudate of the dento-gingival vascular plexus $(1,2$, $3)$. Due to the low compliance of the gingival tissues and the high hydraulic conductance of the crevicular epithelium, the inflammatory exudate carries most of the breakdown products resulting from the periodontal disease process out of the tissues and into the gingival crevice where they appear in the GCF (4). One logical bioassay for periodontal disease activity would be the detection and quantification of these products in GCF.

Collagens account for about $60 \%$ of the total proteins in normal healthy gingiva (5) and are also major constituents of the periodontal ligament and alveolar bone. In the healthy state, a high collagen turnover occurs in both gingiva (6) and periodontal ligament $(7,8)$ and is carried out by fibroblasts via phagocytosis and lysosomal degradation (9, 10). Enhanced production of enzymes capable of degrading collagen is associated with the onset and progression of periodontal disease (11-14) resulting in about a $70 \%$ loss of the collagen in the advancing front of the periodontal lesion (15).

It is generally accepted that degradation of collagen can be monitored by the release of hydroxyproline (Hyp) which makes up about $10 \%$ of this protein. Consequently, in active periodontal disease with increased degradation and a net loss of collagen in the periodontal connective tissue, the GCF would be expected to have increased concentrations of Hyp.

Clq (MW 409 600), a subunit of the first complement factor, contains $4.3 \%$ Hyp by weight (16). Systemic as well as local factors can alter its concentration in the tissues. It is seen coating bacteria collected from gingival crevices in patients with chronic periodontitis (17). Consequently, in order to accurately monitor increased degradation and loss of gingival collagen by determination of Hyp in GCF, it is imperative to remove any $\mathrm{Clq}$ from the samples. This can be done by precipitation of $\mathrm{C} 1 \mathrm{q}$ with a 0.02 $\mathrm{M}$ sodium acetate buffer (18).

The first reasonably sensitive and reproducible procedure for determination of Hyp was described by Neuman \& Logan (19). Because of the complexity of the biological mixtures in which Hyp is being determined, countless modifications or separate procedures have been developed to increase the sensitivity or to improve the specificity of the assay. A few attempts have been made

Table 1. Flow program

\begin{tabular}{|c|c|c|c|c|}
\hline Time & $\begin{array}{c}\text { Flow } \\
(\mathrm{ml} / \mathrm{min})\end{array}$ & $\% \mathrm{~A}^{1}$ & $\% \mathrm{~B}^{2}$ & Curve \\
\hline \multicolumn{4}{|l|}{ Initial } & \\
\hline $\begin{array}{r}\text { tions: } \\
4.0\end{array}$ & $\begin{array}{l}1.0 \\
1.0\end{array}$ & $\begin{array}{l}100 \\
100\end{array}$ & $\begin{array}{l}0 \\
0\end{array}$ & $\begin{array}{l}6 \\
6\end{array}$ \\
\hline 10.0 & 1.0 & 49 & 51 & 5 \\
\hline 10.5 & 1.0 & 0 & 100 & 6 \\
\hline 11.5 & 1.0 & 0 & 100 & 6 \\
\hline 12.0 & 1.5 & 0 & 100 & 6 \\
\hline 12.5 & 1.5 & 100 & 0 & 6 \\
\hline 20.0 & 1.5 & 100 & 0 & 6 \\
\hline 20.5 & 1.0 & 100 & 0 & 6 \\
\hline 30.0 & 1.0 & 100 & 0 & 6 \\
\hline 31.0 & 0.2 & 50 & 50 & 6 \\
\hline
\end{tabular}

${ }^{1}$ A solvent: Sodium acetate $(19 \mathrm{~g})$, water $(1000 \mathrm{ml})$ and triethylamine $(0.5 \mathrm{ml})$ are mixed and titrated to $\mathrm{pH} 6.40$ with glacial acetic acid. Mix $967 \mathrm{ml}$ of this solution with $19.8 \mathrm{ml}$ acetonitrile and $13.2 \mathrm{ml}$ water.

${ }^{2}$ B Solvent: Acetonitrile:water (6:4 by vol.). ${ }^{3}$ Curve: As defined by Waters Associates: \#6 (linear), \#5 (convex). The final $11 \mathrm{~min}$ of the gradient bring the system into stand-by mode after unattended, overnight chromatography. 


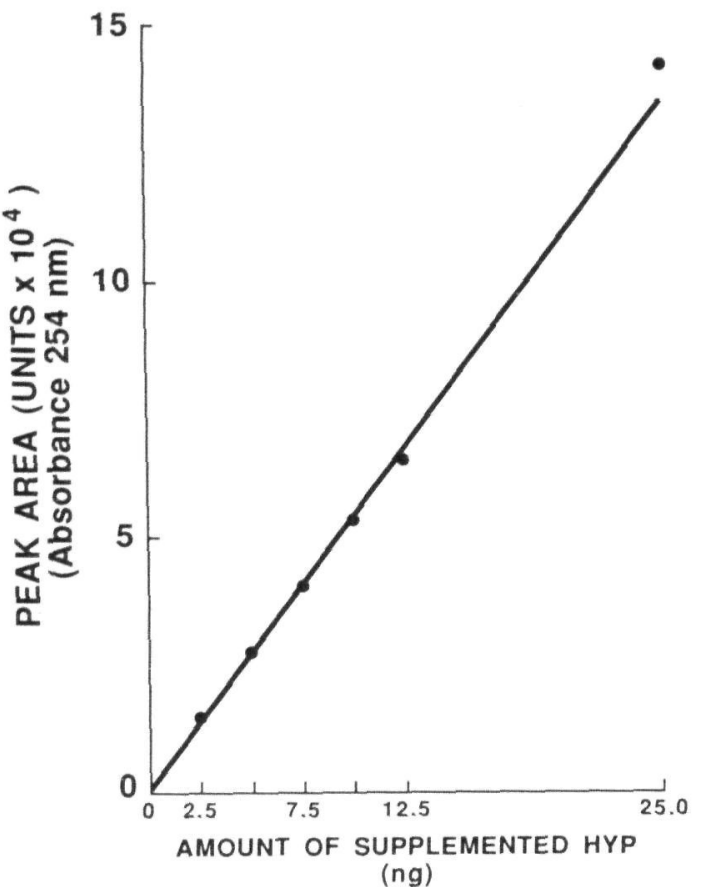

Fig. 1. Standard addition calibration curve $(y=-1914+5707 x ; r=0.99)$ for authentic trans-4-hydroxy-L-proline. Each point represents the mean of five consecutive determinations.

to determine Hyp in GCF. However, the procedures are not sufficiently sensitive and therefore require pooled samples rather than specimens taken from discrete sites (20), and do not take into account the effects of $\mathrm{Clq}(21,22$, 23).

This study presents a high-performance liquid chromatography assay for low nanogram quantities of collagenderived Hyp in 1 to $2 \mu \mathrm{l}$ volumes of GCF and serum.

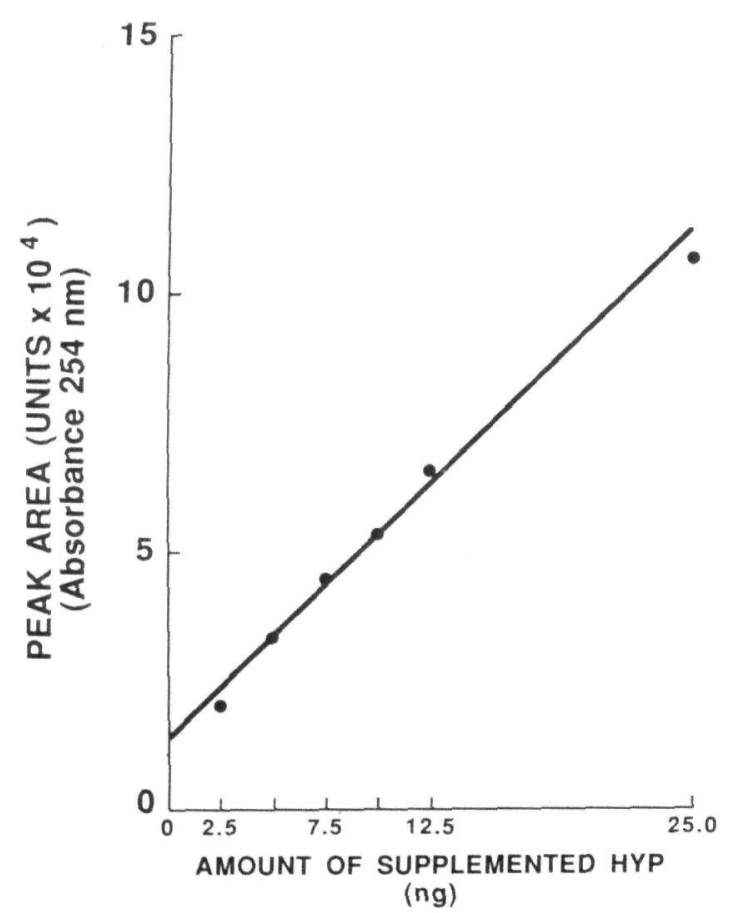

Fig. 2. Standard addition calibration curve $(y=14438+3835 x ;(r=0.99)$ for serum supplemented with trans-4-hydroxy-L-proline before hydrolysis. Each point represents the mean of five consecutive determinations.

\section{Material and Methods Apparatus}

The high-performance liquid chromatography system (Waters Associates, Milford, MA) consisted of the Model 840 Data and Chromatography Control Station, two Model 510 solvent pumps, a Model 441 absorbance detector (fixed wavelength $254 \mathrm{~nm} ; 10 \mathrm{~mm}$ flow cell) and a Model 710B Automatic Sample Processor. A Pico-Tag column was kept at a temperature of $38 \pm 0.1^{\circ} \mathrm{C}$ by means of a Temperature Control System and the eluents were kept under a blanket of helium with an Eluent Stabilization System. A Savant Model SVC100H Speed Vac Concentrator (Savant, Farmingdale, NY) was used for desiccation to avoid splashing of the fluid samples and a Pico-Tag Work Station (Waters Assoc.) was used for vapor hydrolysis of the dried specimens.

\section{Reagents}

HPLC Grade acetonitrile, sodium acetate and methanol were from Fisher Scientific, (Livonia, MI) and glacial acetic acid was from Mallinckrodt (St. Louis, MO). Triethylamine (TEA), phenylisothiocyanate (PITC) and constant boiling hydrochloric acid were Sequanal Grade from Pierce (Rockford,
IL). Pico-Tag Sample Diluent (0.005 M dibasic sodium phosphate titrated to $\mathrm{pH}$ 7.4 with $1 \mathrm{M}$ phosphoric acid:acetonitrile; 19:1 by vol.) was obtained from Waters Associates. Stock solutions of trans4-hydroxy-L-proline and cis-4-hydroxyD-proline (Sigma Chemical Co., St. Louis, MO) were made up to a concentration of $1.25 \mathrm{mg} / 1$, and $2 \mathrm{ml}$ aliquots blanketed with argon were stored at $-20^{\circ} \mathrm{C}$ until used. A $0.02 \mathrm{M}$ sodium acetate buffer (Trihydrate, Grade 1, Sigma Chemical Co.), $\mathrm{pH} 5.5$, was stored at $4^{\circ} \mathrm{C}$ until used.

\section{Standard curves}

Serum was obtained prior to each experiment by collecting blood from a beagle dog foreleg vein with serum separators (Microtainer, Becton Dickinson, Rutherford, NJ) that were left at $4{ }^{\circ} \mathrm{C}$ for $60 \mathrm{~min}$, centrifuged at $12700 \times g$ for 10 min and the serum retrieved.

Standard curves were generated for authentic Hyp (Matrix 1) and authentic Hyp in serum hydrolysate (Matrix 2a). Six concentrations of supplemented Hyp were made up by adding 17.5, 35.0, $52.5,70.0,87.5$ and $175 \mathrm{ng}$ of trans-4hydroxy-L-proline to the samples tubes. In Matrix 1, the Hyp was pipetted into $6 \times 50 \mathrm{~mm}$ borosilicate glass culture tubes (Corning Glass Works, Corning,

Table 2. Precision of assay for trans-4-hydroxy-L-proline expressed as the coefficient of variation $(\mathrm{CV})$ of peak areas for quintuplicate samples of six concentrations of hydroxyproline

\begin{tabular}{lcccc}
\hline Matrix & $\begin{array}{c}\text { Hyp conc. } \\
(\mathrm{ng} / \mu \mathrm{l})\end{array}$ & $\begin{array}{c}\text { Mean peak area } \\
\left(\text { units } \times 10^{4}\right)\end{array}$ & SD & CV $(\%)$ \\
\hline $1^{2}$ & 2.5 & 13994 & 252 & 1.8 \\
& 5.0 & 28639 & 764 & 2.7 \\
& 7.5 & 40413 & 381 & 0.9 \\
& 10.0 & 53977 & 1121 & 2.1 \\
& 12.5 & 65301 & 236 & 0.4 \\
$2 \mathrm{a}^{3}$ & 25.0 & 142850 & 813 & 0.6 \\
& 2.5 & 20689 & 893 & 4.3 \\
& 5.0 & 33252 & 491 & 1.5 \\
& 7.5 & 44799 & 916 & 2.0 \\
& 10.0 & 53457 & 550 & 1.0 \\
& 12.5 & 65918 & 549 & 0.8 \\
$2 \mathrm{~b}^{4}$ & 25.0 & 108202 & 1567 & 1.4 \\
& 2.5 & 6216 & 363 & 5.8 \\
& 5.0 & 11778 & 547 & 4.6 \\
& 7.5 & 14566 & 158 & 1.1 \\
& 10.0 & 20166 & 1631 & 8.1 \\
& 12.5 & 22752 & 767 & 3.4 \\
& 25.0 & 39029 & 761 & 1.9
\end{tabular}

${ }^{1}$ Concentration of supplemented trans-4-hydroxy-L-proline.

${ }^{2}$ Authentic trans-4-hydroxy-L-proline samples that were analyzed in five consecutive runs.

${ }^{3}$ Serum samples that were supplemented with trans-4-hydroxy-L-proline before hydrolysis, and assayed in five consecutive runs.

${ }^{4}$ Serum samples that were supplemented with trans-4-hydroxy-L-proline before hydrolysis, and assayed on different days. 
NY) and the samples were brought to dryness. In Matrix 2a, the Hyp was added to $7 \mu \mathrm{l}$ serum samples in micro sedimentation polypropylene tubes (Sarstedt, St. Louis, MO) and the samples were brought to dryness. Then 100 $\mu \mathrm{l}$ of $0.02 \mathrm{M}$ sodium acetate were added to the tubes that were left overnight at $4^{\circ} \mathrm{C}$ for precipitation of C1q. After centrifugation at $12700 \times g$ for $15 \mathrm{~s}, 90 \mu \mathrm{l}$ of the supernatants were brought to dryness in $6 \times 50 \mathrm{~mm}$ glass culture tubes. Five consecutive series of these samples were processed and chromatographed on the same day for determination of "within-run" precision.

A second series of six concentrations of authentic Hyp in serum (Matrix 2b) was made up by adding $25,50,75,100$, 125 and $250 \mathrm{ng}$ of trans-4-hydroxy-Lproline to $10 \mu \mathrm{l}$ serum in micro sedimentation tubes and the samples were brought to dryness. Precipitation of $\mathrm{C} 1 \mathrm{q}$ was done in $100 \mu \mathrm{l}$ of $0.02 \mathrm{M}$ sodium acetate, as described above, and $10 \mu \mathrm{l}$ aliquots of the supernatants were brought to dryness in $6 \times 50 \mathrm{~mm}$ glass culture tubes. Five series of these samples were processed and chromatographed on different days for determination of "between-run" precision.

\section{Samples}

Three beagle dogs were given weekly prophylaxes and had their teeth brushed every weekday until clinically healthy periodontal tissues were established, as determined by the color and consistency of the gingivae and the absence of GCF following gentle mechanical stimulation of the gingiva. Then dental plaque was allowed to form by refraining from all oral hygiene measures. Starting $1 \mathrm{wk}$ later, samples were collected once per wk over a 5-wk period of developing gingivitis. The animals were fed no later than $24 \mathrm{~h}$ before sampling. GCF from mandibular premolars was collected with tared $2 \mu$ l capillary glass tubes (Drummond Scientific, Broomall, PA) after gentle mechanical stimulation of the gingiva. Again, the tubes were weighed on an analytical balance, after
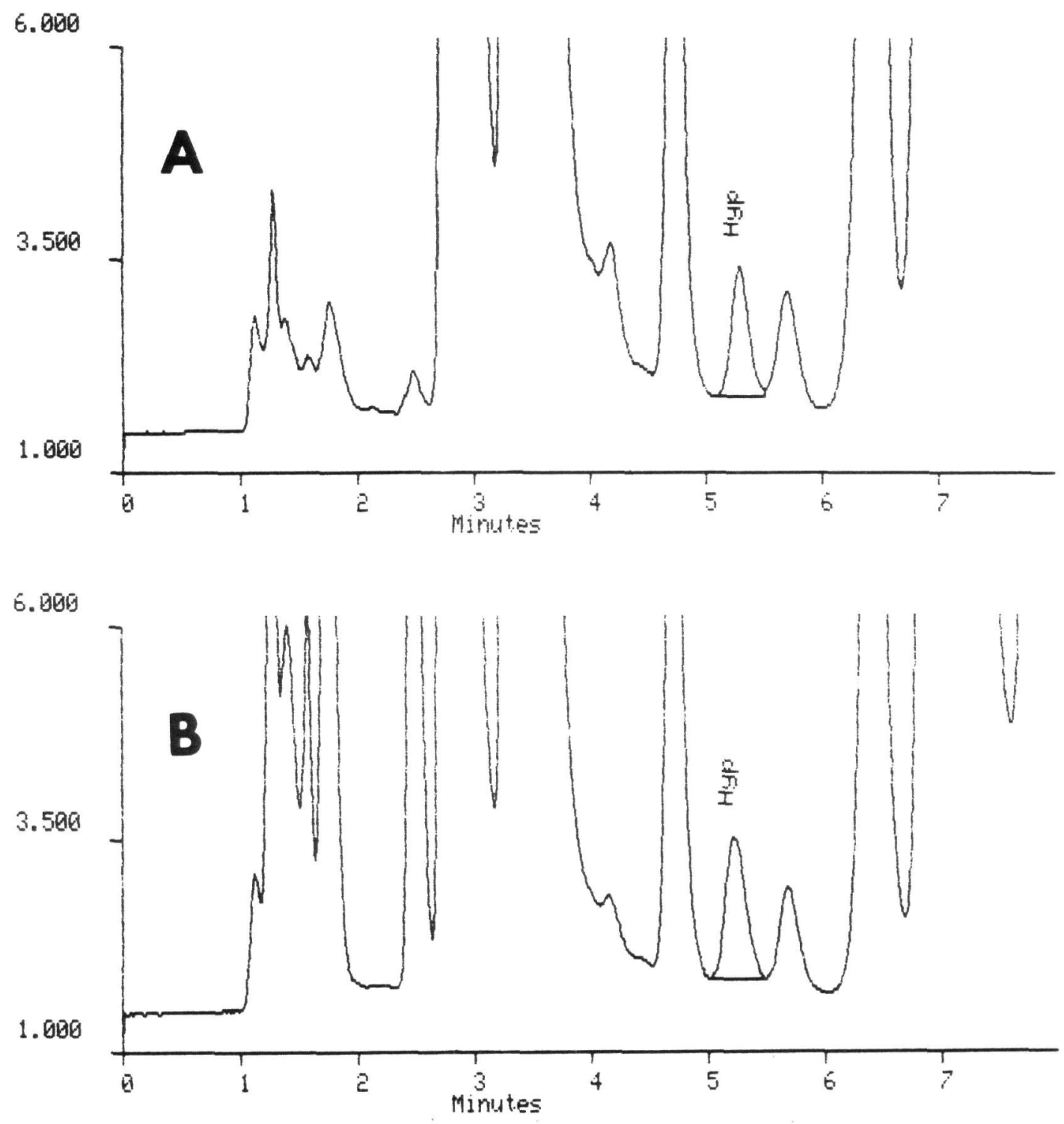

Fig. 3. Chromatograms showing hydroxyproline peak in $A$. Serum $(3.2 \mathrm{ng})$ and $B$. Gingival crevicular fluid $(4.1 \mathrm{ng})$. Retention time is $5.29 \mathrm{~min}$. Attenuation: 0.005 absorbance units full scale. which the GCF samples were retrieved by flushing $60 \mu \mathrm{l}$ of $0.02 \mathrm{M}$ sodium acetate through the microcapillary tubes. After precipitation of Clq, as described above, $50 \mu \mathrm{l}$ of the supernatants were brought to dryness in $6 \times 50 \mathrm{~mm}$ glass culture tubes.

\section{Hydrolysis}

Up to 12 sample tubes were placed in a glass reaction vial with a resealable teflon closure (Waters Assoc.) and $200 \mu \mathrm{l}$ of $\mathrm{HCl}$ were dispensed into the reaction vial, not the sample tubes. Oxygen was removed from the reaction vials by three cycles of alternate evacuation (20 s) and flushing with nitrogen $(5 \mathrm{~s})$ using the Pico-Tag Work Station. The reaction vials were sealed under vacuum at the end of the third cycle. The samples were hydrolyzed at $105^{\circ} \mathrm{C}$ for $24 \mathrm{~h}$ and then brought to dryness.

\section{Derivatization}

Twenty-five microliters of fresh redrying solution (methanol:water:TEA, 2:2:1 by vol.) were added to each sample which was vortexed and brought to dryness. Then $25 \mu \mathrm{l}$ of fresh derivatization solution (methanol:water:TEA:PITC; 7:1:1:1 by vol.) were added to the samples that were vortexed, centrifuged for $20 \mathrm{~s}$ in the Speed Vac Concentrator, left at room temperature for $20 \mathrm{~min}$ and brought to dryness. Seventy microliters of Sample Diluent:methanol (4:1 by vol.) were added to the samples $(35 \mu \mathrm{l}$ to each of the "between-run" samples) that were vortexed for $10 \mathrm{~s}$ and then passed through Millex-HV4 filters into low volume inserts (Waters Assoc.).

\section{Chromatographic conditions}

Two eluents were used: A) Sodium acetate $(19 \mathrm{~g})$, water $(1000 \mathrm{ml})$ and TEA $(0.5 \mathrm{ml})$ were mixed and titrated to $\mathrm{pH}$ 6.40 with glacial acetic acid. Then, 19.8 $\mathrm{ml}$ acetonitrile and $13.2 \mathrm{ml}$ water were added to $967 \mathrm{ml}$ of this solution. B) Acetonitrile:water (6:4 by vol.). The flow program (Table 1) started isocratic with $1 \mathrm{ml} / \mathrm{min}$ of $100 \%$ A solvent for 4 min followed by a gradient washing step for $8.5 \mathrm{~min}$ and a $7.5 \mathrm{~min}$ re-equilibration phase. At $20 \mathrm{~min}$ the system was ready for the injection of $10 \mu \mathrm{l}$ of the next sample. The final $11 \mathrm{~min}$ of the flow program brought the system into a stand-by mode after unattended, overnight chromatography. Before chrom- 

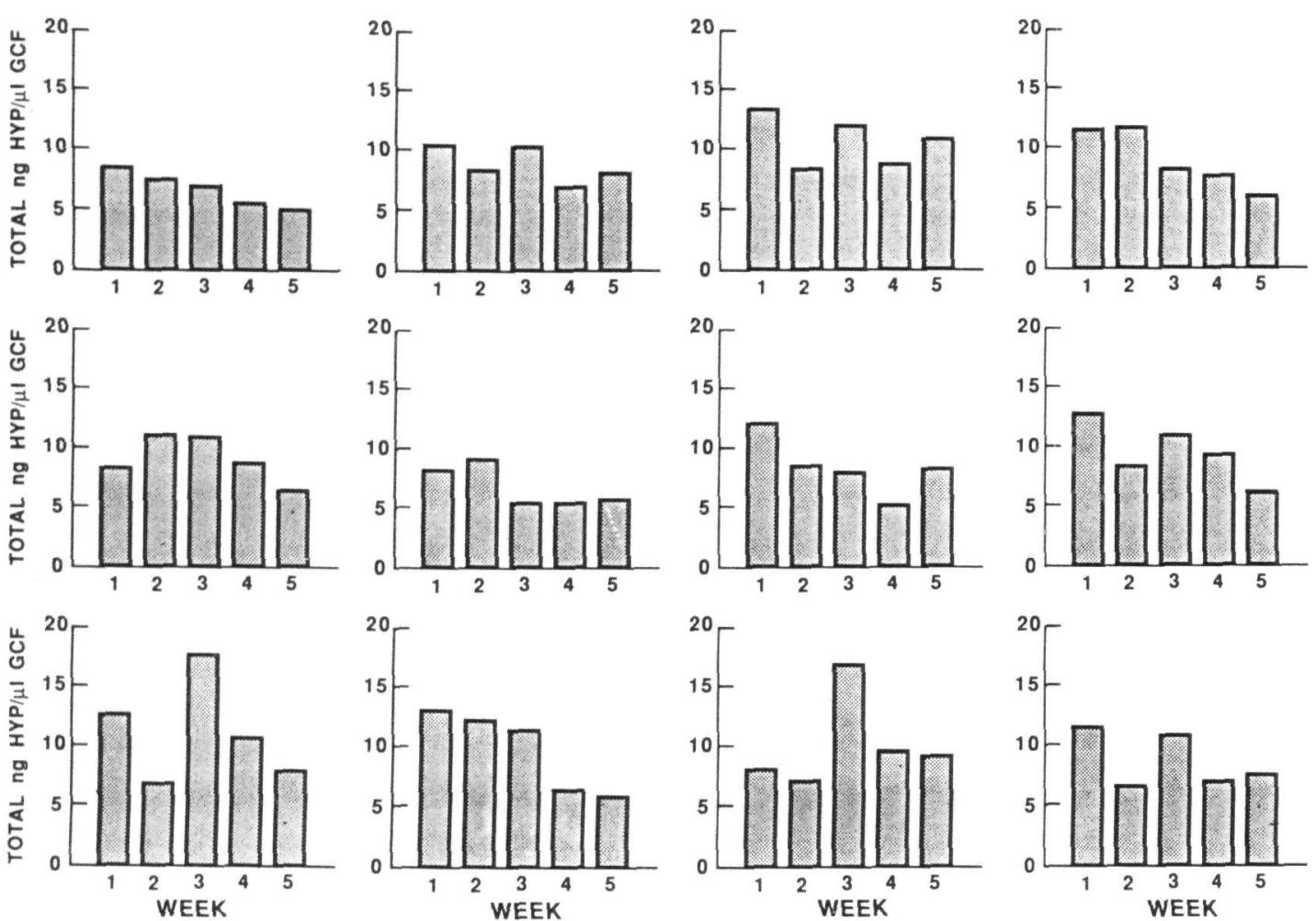

Fig. 4. Variations in total trans-4-hydroxy-L-proline in gingival crevicular fluid from 12 gingival crevices that were sampled 1 to $5 \mathrm{wk}$ after initiation of experimental gingivitis.

atography of the first actual sample, the system was equilibrated by doing at least three blank runs. Absorbance was determined $(254 \mathrm{~nm})$ at a sampling rate of 4 points/s. To save hard disk storage space, only the first 8 min of each chromatogram were recorded for subsequent integration of the peak areas.

\section{Analytical variables}

Calibration curves were generated for quintuplicate samples using the standard-addition method. Peak areas were plotted against concentrations of supplemented Hyp (range 2.5 to $25.0 \mathrm{ng}$ ) for regression analysis. The curves for authentic Hyp and authentic Hyp in serum hydrolysate were compared by analysis of covariance. In each matrix, precision was determined for five samples of six different concentrations of supplemented Hyp by calculating the coefficient of variation (CV). Analytical recovery was determined by comparing the peak areas of six hydrolyzed aliquots of authentic trans-4-hydroxy-Lproline with the mean peak area of six non-hydrolyzed aliquots.

\section{Results}

\section{Standard curves}

The standard curves showed a linear correlation between peak areas (absorbance) and concentration of supplemented trans-4-hydroxy-L-proline (Figs. 1 and 2) with a correlation coef- ficient of 0.99 . The regression equations (Matrix 1: $y=-1914+5707 x$, Matrix 2a: $y=14438+3835 x)$ showed that the calibration curve for Hyp standards in serum hydrolysate had a higher value for the y-intercept, accounted for by the Hyp content in serum, and a significantly $(p<0.0001)$ lower slope factor than the calibration curve for authentic Hyp.

\section{Precision and analytical recovery}

The precision of the assay was determined for all three matrices and, as shown in Table 2, the coefficient of variation for the six concentrations of Hyp ranged from 0.6 to $2.7 \%$ (Matrix 1), 0.8 to $4.3 \%$ (Matrix $2 \mathrm{a}$ ) and 1.1 to $8.1 \%$ (Matrix 2b). The coefficient of variation for the slope factors of the five standard curves in Matrix 2b was 2.5\%. The analytical recovery of the hydrolyzed trans-4-hydroxy-L-proline samples was $90.5 \pm 2.54 \% \quad(\bar{X} \pm \mathrm{SD})$ as compared with the non-hydrolyzed samples.

\section{Clinical samples}

The retention time for Hyp in the GCF samples was the same as for Hyp in Matrix 1, 2a and 2b (5.29 min) with good resolution of the Hyp peak (Fig. 3 ). One week after plaque was allowed to form (Fig. 4), GCF from 12 sites had a concentration of Hyp that ranged from 8.4 to $13.6 \mathrm{ng} / \mu \mathrm{l}(11.3 \pm 2.15 \mathrm{ng} /$ $\mu \mathrm{l} ; \overline{\mathrm{X}} \pm \mathrm{SD}$ ). Over the following 4-wk period, each site showed an irregular pattern of increases and decreases in Hyp concentration in the GCF that ranged from 5.2 to $17.4 \mathrm{ng} / \mu \mathrm{l}(9.0 \pm 2.60$ $\mathrm{ng} / \mu \mathrm{l} ; \overline{\mathrm{X}} \pm \mathrm{SD})$.

\section{Discussion}

A sensitive and reproducible method for the determination of Hyp in GCF and serum has been established. It requires only 1 to $2 \mu$ l volumes of these specimens and has a determination level of about $2 \mathrm{ng}$ of Hyp.

The slope factor of the calibration curve for serum hydrolysates supplemented with trans-4-hydroxy-L-proline prior to hydrolysis was found to be significantly lower than the slope factor of the calibration curve for authentic trans-4-hydroxy-L-proline $(\mathrm{p}<0.0001)$. This might be explained by the demonstrated $9.5 \%$ loss of authentic trans-4hydroxy-L-proline during hydrolysis which has a greater effect on serum samples with higher concentrations of supplemented authentic Hyp and consequently lowers the value of the slope factor. The loss is explained by the epimerization of approximately $10 \%$ of the trans-4-hydroxy-L-proline to cis-4hydroxy-D-proline (24) that does not elute with the trans isomer.

In the five experiments performed on different days (Matrix 2b) the coefficient of variation for the slope factors of the standard curves was as low as $2.5 \%$ and the coefficient of variation for determination for the six concentrations of Hyp was only $4.2 \pm 2.59 \%(\overline{\mathrm{X}} \pm \mathrm{SD})$. Therefore, external standards were considered appropriate and manageable for the low level analyses of the small volume clinical samples, assuming that they would add the least measurement error to the assay.

There was no need for any sample clean-up other than precipitation of Clq despite the fact that the protein concentration in GCF can be as high as $93 \mu \mathrm{g} / \mu \mathrm{l}$ (25). However, to maintain established chromatographic conditions, $20 \mathrm{ml}$ of methanol was pumped through the column (flow rate $0.2 \mathrm{ml} /$ min; column temperature $38^{\circ} \mathrm{C}$ ) after every 40-50 clinical samples which consistently eluted substantial amounts of contaminants that had been retained on the column.

When changing to a new Pico-Tag column, a slight modification of the A solvent was required to achieve the optimal retention time and resolution of the Hyp peak. This was accomplished by 
an increase or decrease $( \pm 2 \mathrm{ml})$ in the amount of acetonitrile that was added to the acetate buffer.

The clinical samples showed variations in Hyp concentration with differences between sites and within sites over time. High and low values appeared in an irregular pattern during the first 5 wk of experimental gingivitis which suggests that, during this period of collagen breakdown in the gingival connective tissue (26), the metabolism of this protein is an irregular rather than a linearly continuous event.

Leukocytes capable of releasing substantial amounts of hydrolytic enzymes accumulate in the gingival tissues during the onset and progression of periodontal disease (15). Collagenase is found at the advancing front of the periodontal lesion (27) and the collagenolytic activity increases with increasing severity and activity of the disease (28, 29). In addition to extracellular degradation of mature collagen, intracellular degradation of newly synthesized collagen occurs. The basal level of intracellular degradation of nascent collagen in healthy connective tissue is estimated to be $15 \pm 5 \%$ and has minimal effect on collagen production (30). However, enhanced intracellular degradation above the baseline level occurs when underhydroxylated, non-helical collagen is synthesized (31) and when the fibroblasts are exposed to agents such as prostaglandin $E_{2}$ that increase intracellular levels of cAMP (32). In fact, the concentrations of prostaglandin $\mathrm{E}_{2}$ and cAMP increase in the gingival tissues with increasing severity of the disease $(33,34$, $35)$. In addition, collagen-poor, cell-rich gingival connective tissue incorporates more $\left[\mathrm{G}-{ }^{3} \mathrm{H}\right]$-proline in vitro than does healthy tissue and a larger portion of the protein-bound activity is found in the culture medium (36) suggesting an increased synthesis of collagen in the diseased tissue. Since there is no accumulation of collagen, there is reason to believe that the reported increase in synthesis is counterbalanced by an enhanced intracellular degradation of nascent collagen.

Because of the high collagen turnover rate in gingiva, zero production of collagen due to enhanced intracellular degradation may contribute to loss of collagen in periodontal disease (6). Consequently, the amount of collagen-derived Hyp in GCF from this process, as well as extracellular degradation of mature collagen, may reflect collagen loss and disease activity in the periodontal disease process. Therefore, this sensitive and reproducible method for determination of Hyp in complex biological samples may serve as a useful, non-invasive assay for loss of collagen during progressive periodontal disease and may have the potential for assessment of periodontal disease activity.

\section{Acknowledgment}

This work was supported by NIH Grant DE06953.

\section{References}

1. Brill N, Krasse B. The passage of tissue fluid into the clinically healthy gingival pocket. Acta Odontol Scand 1958; 16: 233.

2. Brill N, Bjorn H. Passage of tissue fluid into human gingival pockets. Acta Odontol Scand 1959; 17: 11.

3. Salkind A, Oshrain HT, Mandel ID. Observations on gingival pocket fluid. Periodontics 1963; 1: 196.

4. Pashley DH. A mechanistic analysis of gingival fluid production. $J$ Periodont Res 1976; 11: 121.

5. Page RC. Macromolecular interactions in the connective tissue of the periodontium. In: Slavkin H, Bavetta L, eds. Developmental aspects of oral biology. New York: Academic Press, 1972: 291.

6. Page RC, Ammons WF. Collagen turnover in the gingiva and other mature connective tissues of the marmoset Sanguinus oedipus. Arch Oral Biol 1974; 19: 651 .

7. Kameyama Y. Autoradiographic study of ${ }^{3} \mathrm{H}$-proline incorporation by rat periodontal ligament, gingival connective tissue and dental pulp. J Periodont Res 1975; 10: 98

8. Sodek J. A new approach to assessing collagen turnover by using a micro-assay. A highly efficient and rapid turnover of collagen in rat periodontal tissues. Biochem J 1976; 160: 243.

9. Eley BM, Harrison JD. Intracellular collagen fibrils in the periodontal ligament of man. J Periodont Res 1975; 10: 168.

10. Rose GG, Yajima T, Mahan CJ. Human gingival fibroblast cell lines in vitro. I. Electron microscopic studies of collagenolysis. J Periodont Res 1980; 15: 53.

11. Taichman NS, McArthur WP. Interaction of inflammatory cells and oral bacteria: Release of lysosomal hydrolyses from rabbit polymorphonuclear leukocytes exposed to gram-positive plaque bacteria. Arch Oral Biol 1976; 21: 257.

12. Taichman NS, Tsai CC, Baehni PC, et al. Interaction of inflammatory cells and oral microorganisms. IV. In vitro release of lysosomal constituents from polymorphonuclear leukocytes exposed to supra- gingival and subgingival plaque. Infect Immun 1977; 16: 1013.

13. Wahl LM, Olsen CE, Sandberg AL, et al. Prostaglandin regulation of macrophage collagenase production. Proc Natl Acad Sci USA 1977; 74: 4955.

14. Page RC, Davies P, Allison AC. The macrophage as a secretory cell. Int Rev $C y$ tol 1978; 52: 119.

15. Schroeder HE, Munzel-Pedrazzoli S, Page RC. Correlated morphometric and biochemical analysis of gingival tissues. The early lesion in man. Arch Oral Biol 1973; 18: 899 .

16. Reid KEM, Lowe DM, Porter RR. Isolation and characterization of $\mathrm{Clq}$, a subcomponent of the first component of complement, from human and rabbit sera. Biochem J 1972; 130: 749.

17. Chisikovsky J, Toto PD, Garguilo AW. $\mathrm{Clq}$ and $\mathrm{C} 4$ detection on bacterial plaque organisms. J Periodontol 1982; 53: 688 .

18. Lepow IH, Naff GB, Todd EW, et al. Chromatographic resolution of the first component of human complement into three activities. $J$ Exp Med 1963; 117: 983.

19. Neuman RE, Logan MA. The determination of hydroxyproline. $J \mathrm{Biol}$ Chem 1950; 184: 299.

20. Hara K, Takahashi T. Hydroxyproline content in gingival exudate before and after periodontal surgery. $J$ Periodont Res 1975; 10: 270.

21. Paunio K. On the hydroxyproline-containing components in the gingival exudate. J Periodont Res 1971; 6: 115.

22. Miller RA, Wynkoop JR, Johannsen K. Analysis of hydroxyproline in gingival exudate by High Performance Liquid Chromatography (Abstract). J Dent Res 1982; 61: (Special Issue) 275.

23. Wynkoop JR, Woodyard S, Miller RA. A comparison of individual crevicular fluid hydroxyproline levels to periodontal assessments (Abstract). J Dent Res 1982; 61: (Special Issue) 315.

24. Dziewiatkowsky DD, Hascall VC, Riolo RL. Epimerization of trans-4-HydroxyL-proline to cis-4-Hydroxy-D-proline during acid hydrolysis of collagen. Anal Biochem 1972; 49: 550.

25. Hattingh $\mathrm{J}, \mathrm{Ho} \mathrm{E}$. The concentration of proteins in human gingival crevicular fluid. J Periodont Res 1980; 15: 90.

26. Page RC, Schroeder HE. Pathogenesis of inflammatory periodontal disease. Lab Invest 1976; 33: 235 .

27. Woolley DE, Davies RM. Immunolocalization of collagenase in periodontal disease. J Periodont Res 1981; 16: 292.

28. Geiger S, Harper E. Human gingival collagenase in periodontal disease: The release of collagenase and the breakdown of endogenous collagen in gingival explants. J Dent Res 1980; 59: 11.

29. Yanagimura M, Hara K, Nohara $H$. Collagenase activities in healthy and in- 
flamed gingiva of dogs. $J$ Periodont Res 1983; 18: 1 .

30. Bienkowski RS. Intracellular degradation of newly synthesized collagen. Coll Relat Res 1984; 4: 399.

31. Berg RA, Schwartz ML, Crystal RG. Regulation of the production of secretory proteins: Intracellular degradation of newly synthesized "defective" collagen. Proc Natl Acad Sci USA 1980; 77: 4746.

32. Baum BJ, Moss J, Breul SD, et al. Effect of cyclic AMP on the intracellular degradation of newly synthesized collagen. $J$ Biol Chem 1980; 255: 2843.
33. Elattar TMA, Lin HS. The relationship between inflammation and cAMP level in human gingiva. Clin Sci 1981; 60: 674.

34. Dewhirst FE, Moss DE, Offenbacher S, et al. Levels of prostaglandin $E_{2}$, thromboxane, and prostacyclin in periodontal disease. J. Periodont Res 1983; 18: 156.

35. Ohm K, Albers H-K, Lisboa BP. Measurement of eight prostaglandins in human gingival and periodontal disease using high pressure liquid chromatography and radioimmunoassay. $J$ Periodont Res 1984; 19: 501.

36. Page RC, Narayanan AS, Schroeder HE.
Connective tissue composition and collagen synthesis in diseased and normal gingiva of adult dogs with spontaneous periodontitis. Arch Oral Biol 1980; 25 . 727.

Address:

Dr. Gunnar K. Svanberg University of Michigan

School of Dentistry 1011 N. University Ann Arbor, Michigan 48109 U.S.A. 
This document is a scanned copy of a printed document. No warranty is given about the accuracy of the copy. Users should refer to the original published version of the material. 